\title{
Additional Calculation and information
}

For Review - Not for Publish

\section{Section Properties}

TheUHPC tower segment is a pretension precast tapered pipe made from steel fiber reinforced ultra-high performance concrete (UHPC), thus transformed sectional properties will be used in the following calculation.

\subsection{Material Properties}

The following present the material properties of UHPC both at transfer and at service stages.

\begin{tabular}{|l|c|c|}
\hline & $\begin{array}{c}\text { At transfer } \\
(\mathbf{t}=\mathbf{2} \text { days })\end{array}$ & $\begin{array}{c}\text { At service } \\
(\mathbf{t}=\text { infinity })\end{array}$ \\
\hline Characteristic Cube Compressive Strength, $\mathrm{f}_{\mathrm{Ucu}}(\mathrm{MPa})$ & 85 & 165 \\
\hline Characteristic Cyl. Compressive Strength, $\mathrm{f}_{\mathrm{Ucu}}(\mathrm{MPa})$ & 80 & 160 \\
\hline Characteristic Compressive Strength, $\mathrm{f}_{\mathrm{Uck}}(\mathrm{MPa})$ & 70 & 150 \\
\hline Density of Concrete $\left(\mathrm{kg} / \mathrm{m}^{3}\right)$ & 2450 & 2450 \\
\hline Characteristic Elastic Tensile Strength, $\mathrm{f}_{\mathrm{U}, \mathrm{tek}}(\mathrm{MPa})$ & 4 & 7.0 \\
\hline Characteristic Ultimate Tensile Strength, $\mathrm{f}_{\mathrm{U}, \text { tuk }}(\mathrm{MPa})$ & 4 & 0 (at joint) \\
\hline Modulus of Elasticity, E $\mathrm{U}_{\mathrm{U}}(\mathrm{GPa})$ & 0 (at joint) & 0 (at joint) \\
\hline
\end{tabular}


The following present the material properties of prestressed strand used.

\begin{tabular}{|l|c|}
\hline Type & S15 \\
\hline Diameter $(\mathrm{mm})$ & 15.2 \\
\hline Density of Steel $\left(\mathrm{kg} / \mathrm{m}^{3}\right)$ & 7840 \\
\hline Type & Low Relaxation \\
\hline Nominal Section $\left(\mathrm{mm}^{2}\right)$ & 140 \\
\hline Nominal Weight $(\mathrm{kg} / \mathrm{m})$ & 1.10 \\
\hline Specified Breaking Load $(\mathrm{kN})$ & 260 \\
\hline Specified Load at $1 \%$ Elongation $(\mathrm{kN})$ & 235 \\
\hline Modulus of Elasticity, $\mathrm{E}_{\mathrm{p}}(\mathrm{GPa})$ & 195 \\
\hline $\mathrm{n}_{\mathrm{p}}$ & 3.88 (at transfer) \\
\hline
\end{tabular}

The following present the material properties of steel reinforcement used.

\begin{tabular}{|l|c|c|c|c|c|c|}
\hline & \multicolumn{5}{|c|}{ Steel Reinforcement Grade460 (BS4449) } \\
\hline \multicolumn{1}{|c|}{ Type } & T10 & T12 & T16 & T20 & T25 & T32 \\
\hline Dia. $(\mathrm{mm})$ & 10 & 12 & 16 & 20 & 25 & 32 \\
\hline Density of Steel $\left(\mathrm{kg} / \mathrm{m}^{3}\right)$ & 7840 & 7840 & 7840 & 7840 & 7840 & 7840 \\
\hline$A_{s}\left(\mathrm{~mm}^{2}\right)$ & 79 & 113 & 201 & 314 & 491 & 804 \\
\hline$E_{S}(\mathrm{GPa})$ & 200 & 200 & 200 & 200 & 200 & 200 \\
\hline$\sigma_{s y}(\mathrm{MPa})$ & 460 & 460 & 460 & 460 & 460 & 460 \\
\hline$\varepsilon_{s y}$ & 0.002 & 0.002 & 0.002 & 0.002 & 0.002 & 0.002 \\
\hline$F_{s y}(\mathrm{kN})$ & 36 & 52 & 92 & 115 & 226 & 370 \\
\hline
\end{tabular}




\subsection{Transformed Section Properties of Girder}

The section modulus ratios for strands are taken as $n_{p}=E_{p} / E_{c}$. Thus at transfer and service the $n$ values are:

- $\quad n_{\text {transfer }}=195 / 40=\mathbf{4 . 8 8} n_{\text {service }}=195 / 50=\mathbf{3 . 9}$

\section{At transfer and Service}

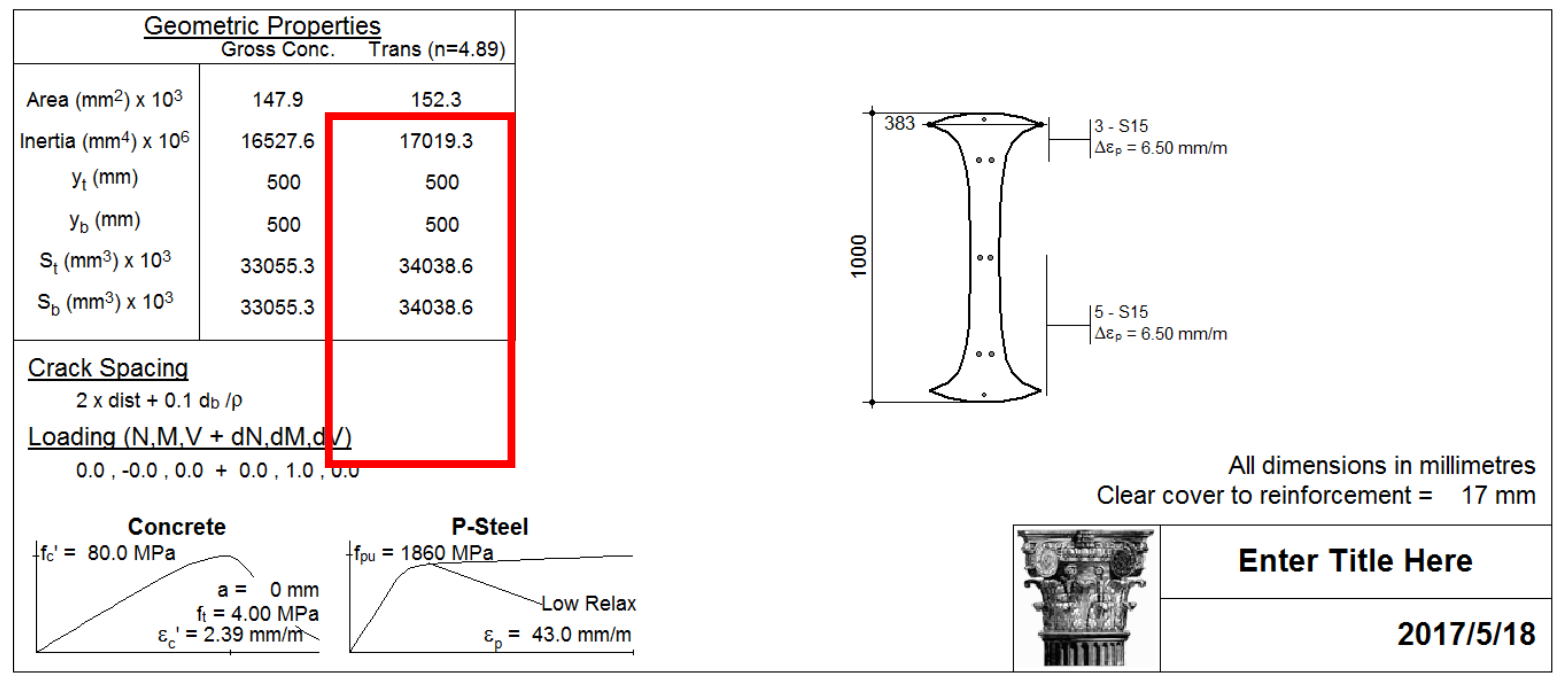

\section{At Transfer}

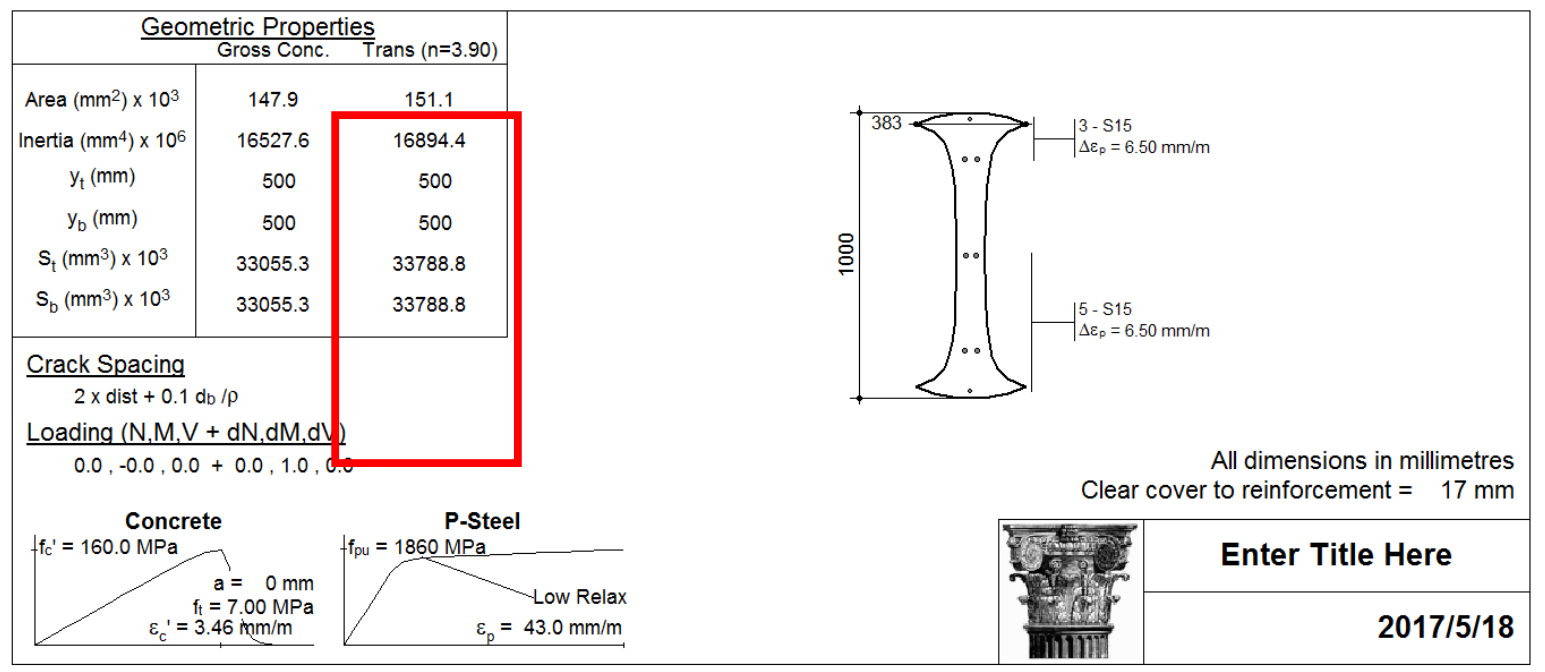

At Service 


\begin{tabular}{|l|c|c|}
\hline & At transfer (t = 2 days) & At service (t = infinity) \\
\hline $\mathrm{n}$ & 4.33 & 3.9 \\
\hline $\mathrm{A}\left(\mathrm{mm}^{2}\right)$ & 152,300 & 151,100 \\
\hline $\mathrm{I}_{\mathrm{xx}}\left(\times 10^{9} \mathrm{~mm}^{4}\right)$ & 17.02 & 16.89 \\
\hline $\mathrm{y}_{\mathrm{t}}(\mathrm{mm})$ & 500 & 500 \\
\hline $\mathrm{y}_{\mathrm{b}}(\mathrm{mm})$ & 500 & 500 \\
\hline $\mathrm{Z}_{\mathrm{t}}\left(\mathrm{x} 10^{6} \mathrm{~mm}^{3}\right)$ & 34.04 & 33.79 \\
\hline $\mathrm{Z}_{\mathrm{b}}\left(\mathrm{x} 10^{6} \mathrm{~mm}^{3}\right)$ & 34.04 & 33.79 \\
\hline
\end{tabular}

\section{Serviceability Calculation}

\subsection{At Transfer}

Assume all the PT strands prestress to $75 \%$ of its breaking load (i.e. $260 \mathrm{kN}$ ) and the strands immediately have $5 \%$ of losses during transfer. Besides, the long term losses is taken as another $10 \%$ where the pipe has undergone all time-effect losses, such as creep and shrinkage and relaxation of the tendons.

Therefore the jacking force for each strands is $P_{j}=260 \mathrm{kN} \times 0.75=195 \mathrm{kN}$

The initial prestressed force $\mathrm{P}_{\mathrm{i}}=0.95 \mathrm{P}_{\mathrm{j}}=0.95 \times 195=185.25 \mathrm{kN}$ (use at transfer, $\mathrm{t}=2$ days)

The effective prestressed force $\mathrm{P}_{\mathrm{e}}=0.90 \times \mathrm{P}_{\mathrm{i}}=0.9 \times 185.25=167 \mathrm{kN}$ (use at service, $\mathrm{t}=$ infinity)

The concrete stress limits used are: 


\section{At transfer:}

- $\quad 0.6 \mathrm{f}_{\mathrm{Uck}}=0.6 \times 70=42 \mathrm{MPa} \quad$ (for compression)

- $\mathrm{f}_{\mathrm{td}}=\mathrm{f}_{\mathrm{U}, \mathrm{etk}} / \gamma_{\mathrm{c}}=4.0 / 1.0=4 \mathrm{MPa} \quad$ (for tension) at monolithic section

The extreme fiber stresses during transfer at the support regions(ends of beam) are:

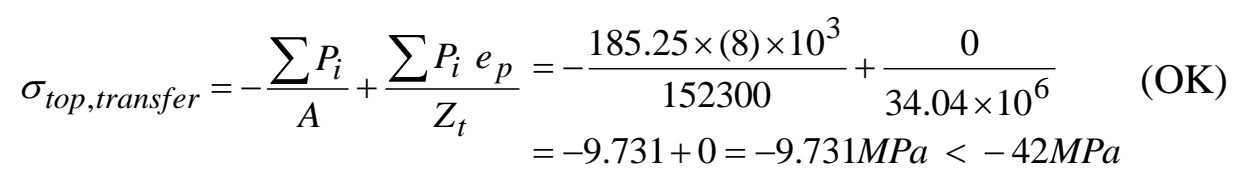

The resultant stress at the top flange is -9.73 MPain compression, which is less than the stress limit of the concrete in compression at transfer.

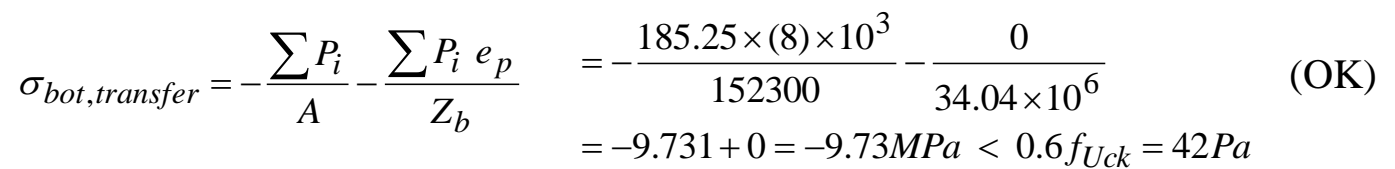

The resultant stress at the bottom flange is $-9.73 \mathrm{MPa}$ in compression, which is a lot less than the stress limit of concrete in compression. In another word, UHPC prestressed pipe has plenty of reserve compression capacity and crushing of the concrete can never occur.

\section{Therefore, the beam will not crack or crush at any section during transfer of the prestressing.}

\subsection{At Service}

Assume all the PT strands prestress to $75 \%$ of its breaking load (i.e. $260 \mathrm{kN}$ ) and the strands immediately have $5 \%$ of losses during transfer. Besides, the long-term losses is taken as another $10 \%$ where the pipe has undergone all time-effect losses, such as creep and shrinkage.

Therefore the jacking force for each strands is $P_{j}=260 \mathrm{kN} \times 0.75=195 \mathrm{kN}$ 
The initial prestressed force $\mathrm{P}_{\mathrm{i}}=0.95 \mathrm{P}_{\mathrm{j}}=0.95 \times 195=185.25 \mathrm{kN}$ (use at transfer, $\mathrm{t}=28$ days)

The effective prestressed force $\mathrm{P}_{\mathrm{e}}=0.90 \times \mathrm{P}_{\mathrm{i}}=0.90 \times 185.25=167 \mathrm{kN}$ (use at service, $\mathrm{t}=$ infinity)

The concrete stress limits used are:

At service:

- $0.6 \mathrm{f}_{\mathrm{Uck}}=0.6 \times 150=90 \mathrm{MPa} \quad$ (for compression)

- $\mathrm{f}_{\mathrm{td}}=\mathrm{f}_{\mathrm{U}, \mathrm{etk}} / \gamma_{\mathrm{c}}=7.0 / 1.0=7 \mathrm{MPa} \quad$ (for tension) at monolithic section

The extreme fiber stresses during transfer at the support regions (ends of beam) are:

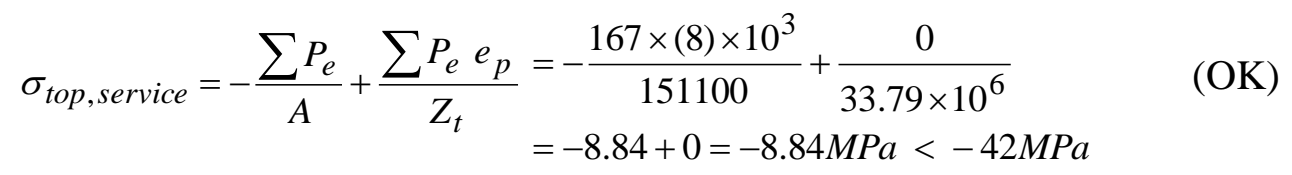

The resultant stress at the top flange is $-9.73 \mathrm{MPa}$ in compression, which is less than the stress limit of the concrete in compression at transfer.

$$
\begin{aligned}
\sigma_{\text {bot }, \text { service }}=-\frac{\sum P_{e}}{A}-\frac{\sum P_{e} e_{p}}{Z_{b}} & =-\frac{167 \times(8) \times 10^{3}}{151100}+\frac{0}{33.79 \times 10^{6}} \quad(\mathrm{OK}) \\
& =-8.84+0=-8.84 \mathrm{MPa}<-42 \mathrm{MPa}
\end{aligned}
$$

The resultant stress at the bottom flange is $-8.84 \mathrm{MPa}$ in compression, which is a lot less than the stress limit of concrete in compression. In another word, UHPC prestressed pipe has plenty of reserve compression capacity and crushing of the concrete can never occur.

\section{Therefore, the pipe will not crack or crush.}


To find the cracking moment of the pipe when the pipe is $1 \mathrm{~m}$ diameter.

$f_{\text {Utek }}=-8.84+\frac{M_{c r}}{Z_{b}}$

$7=-8.84+\frac{M_{c r}}{33.79}$

Therefore the cracking moment is $535 \mathrm{kNm}$.

\section{Ultimate Strength Calculation}

\subsection{Design Moment Resistance $\left(M_{R d}\right)$}

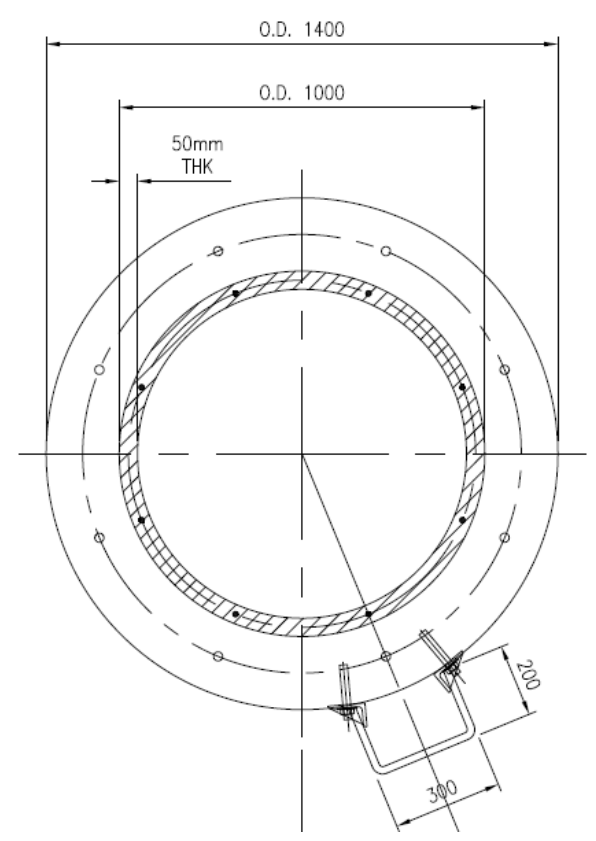

The design moment resistance can be easily calculated using the moment equilibrium method. First calculated the factored design tendon tension forces.

The material factor used for the strands is 1.15 .

The material factor used for the UHPC is 1.3 .

A rectangular stress block for the compression part is used assume in the top flange. The factored compressive stress can be taken as $\mathrm{f}_{\mathrm{Uck}} / \gamma=150 / 1.3=115 \mathrm{MPa}$. Then using force equilibrium 
method. Sum of $\mathrm{C}$ must be equal to Sum of T. In this calculation the top tendon is ignored. The next step is to find $\mathrm{X}$.

Response2000 gives a value of $\mathrm{M}_{\mathrm{Rd}}=838 \mathrm{kNm}$.

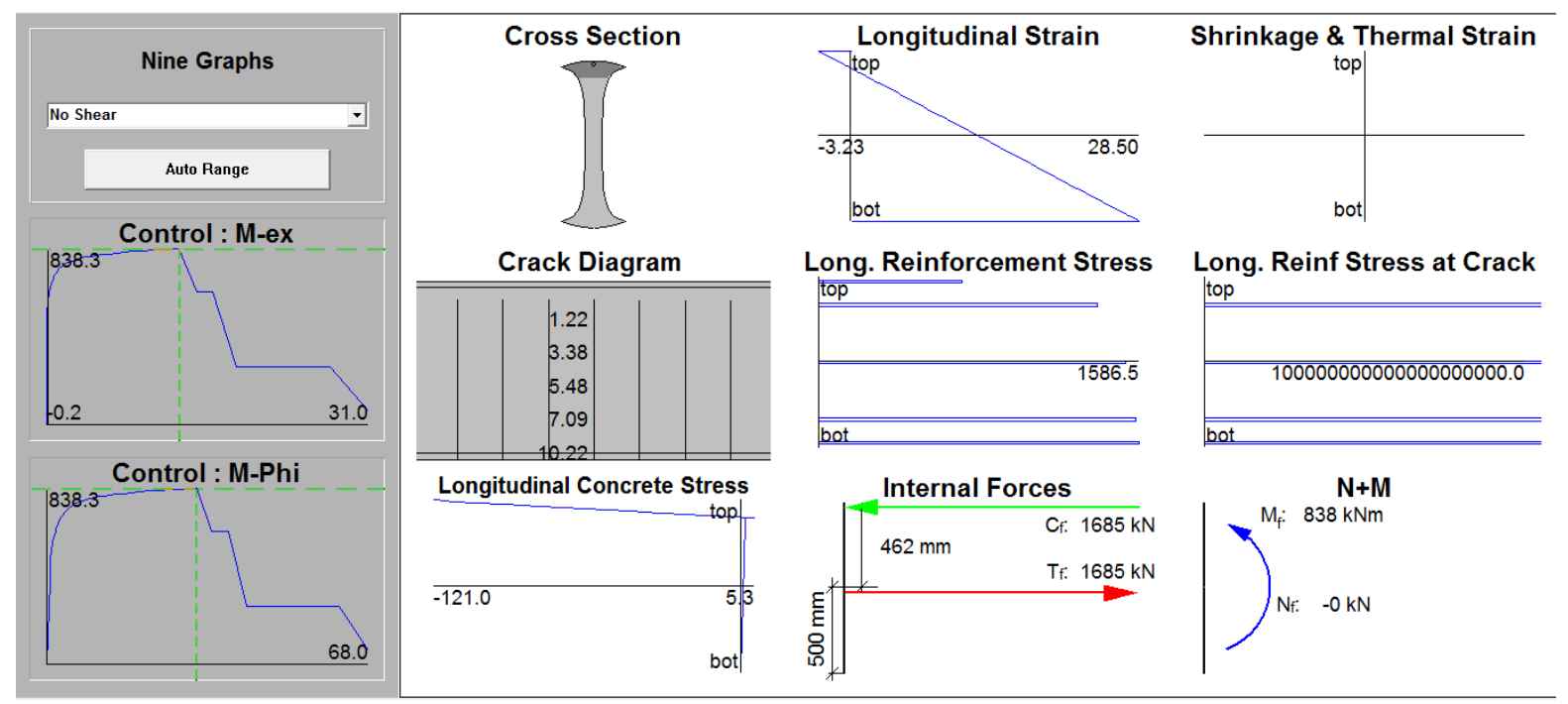




\section{Design Drawings for Details}

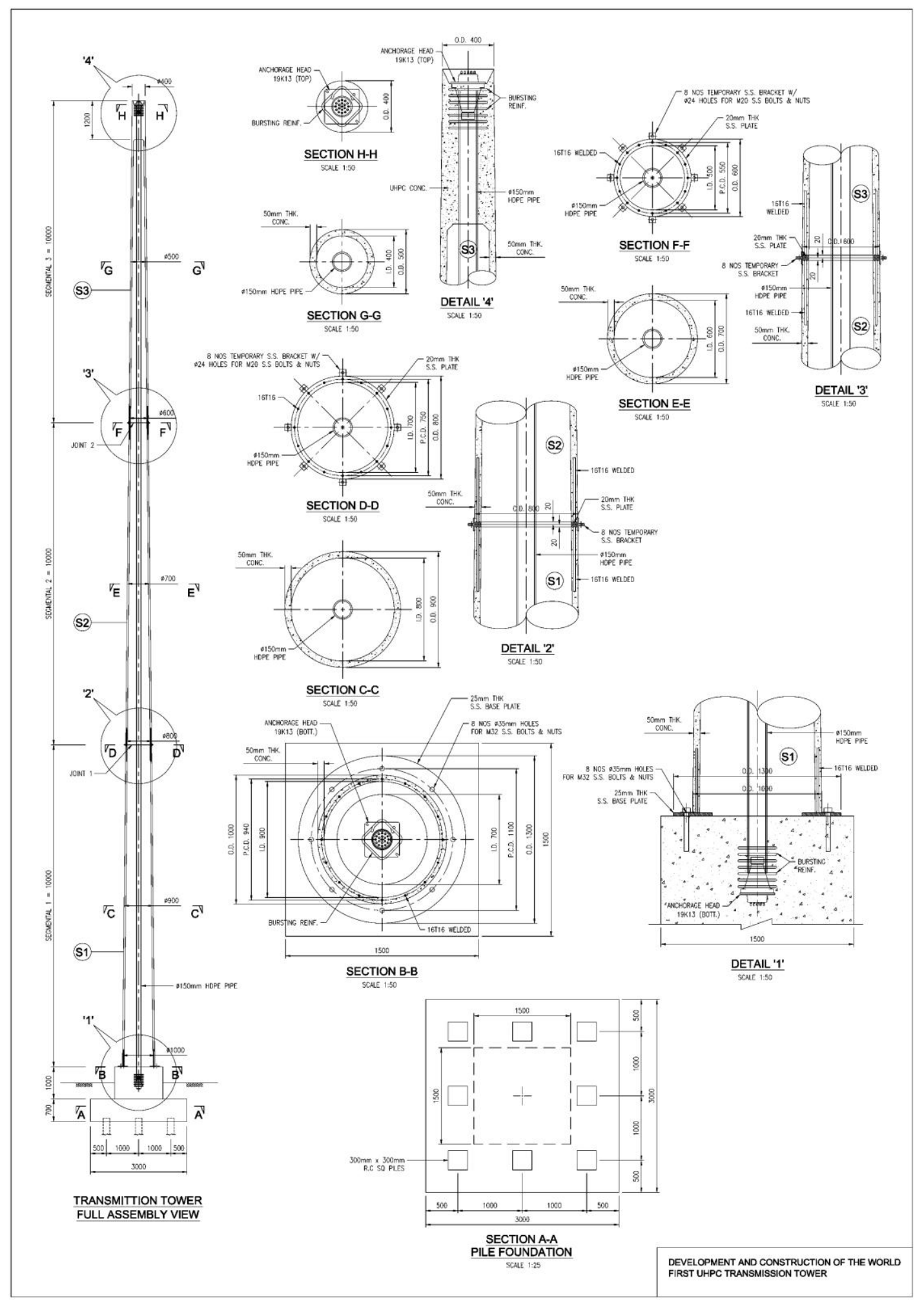




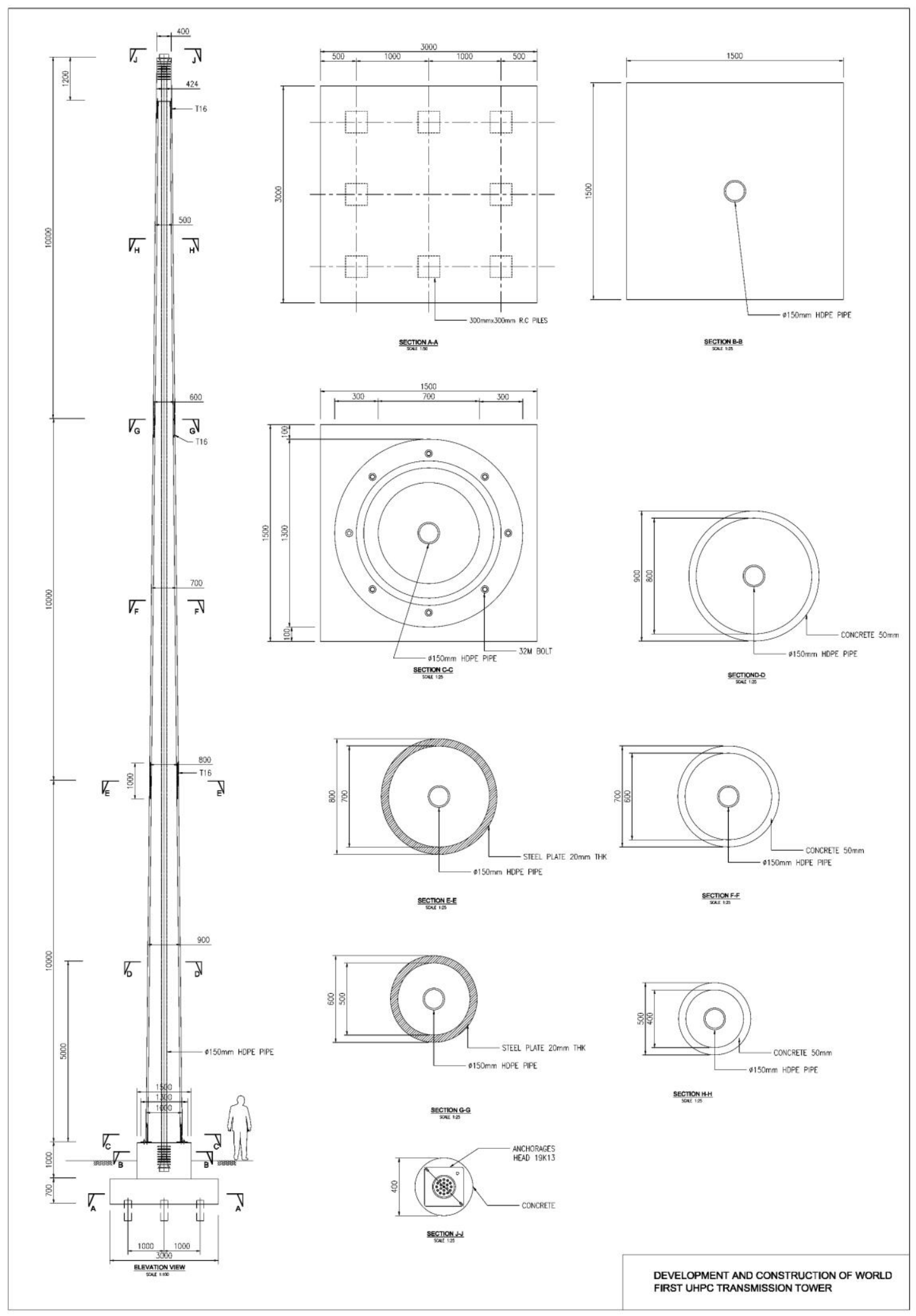




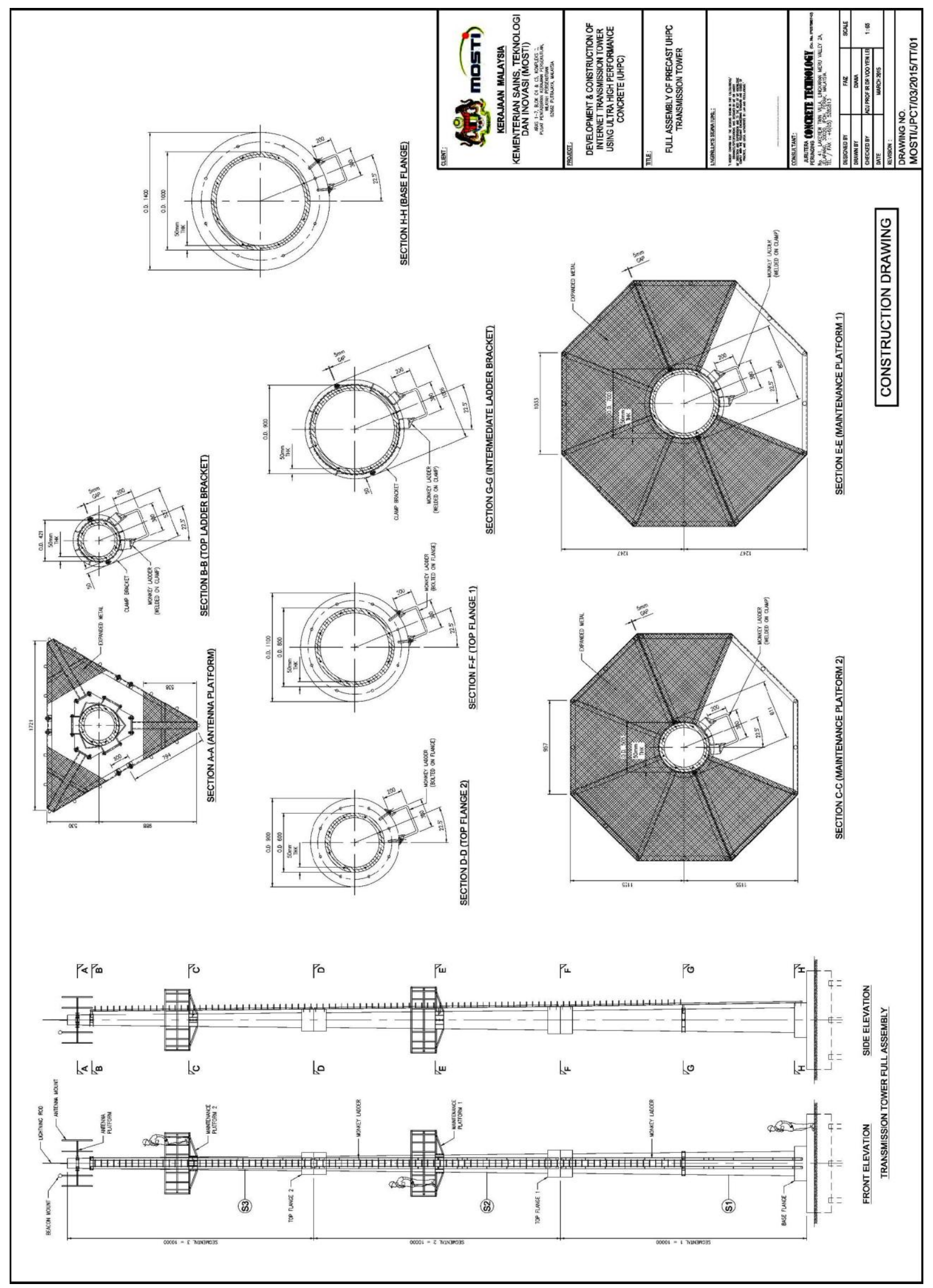




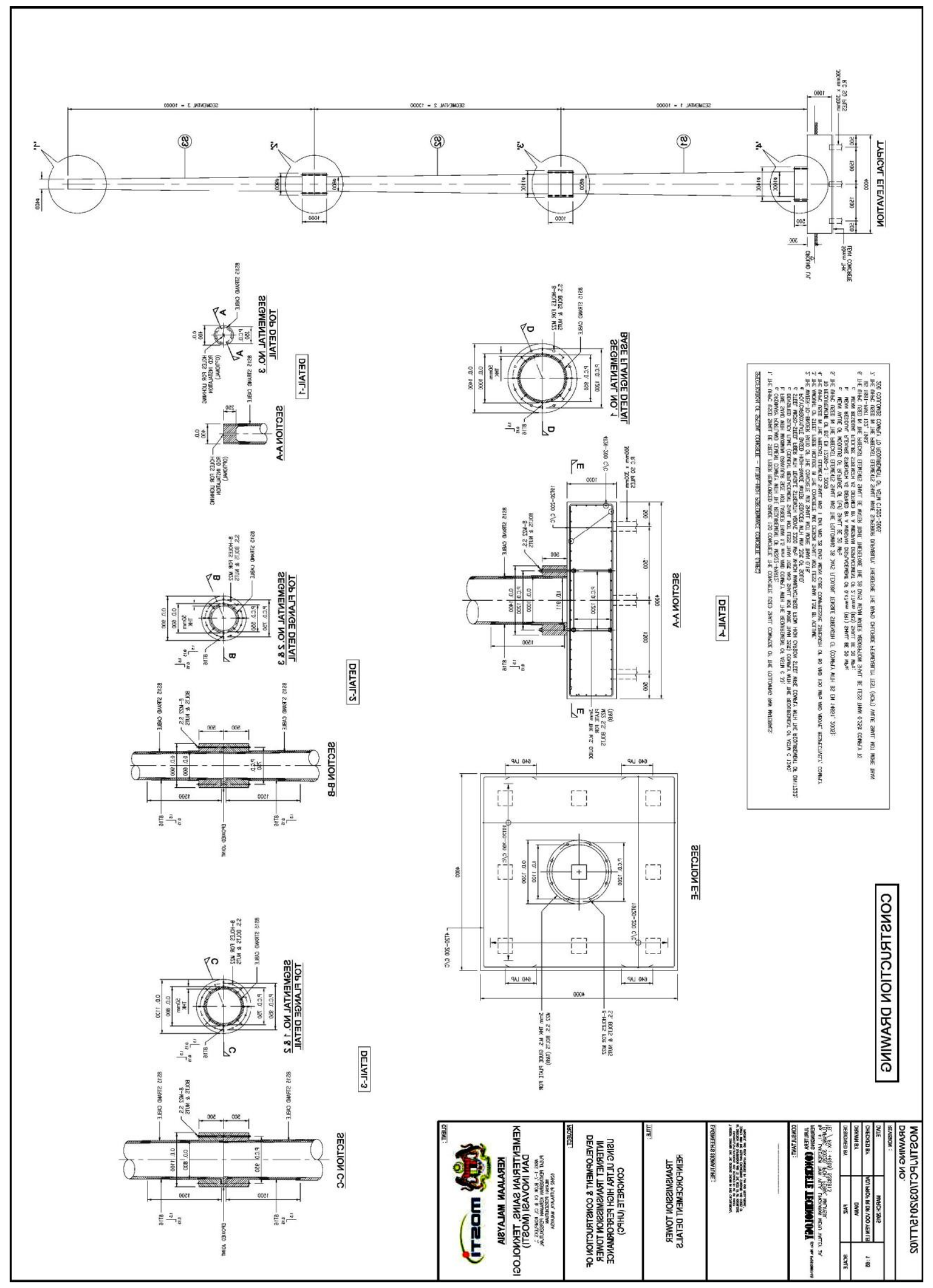




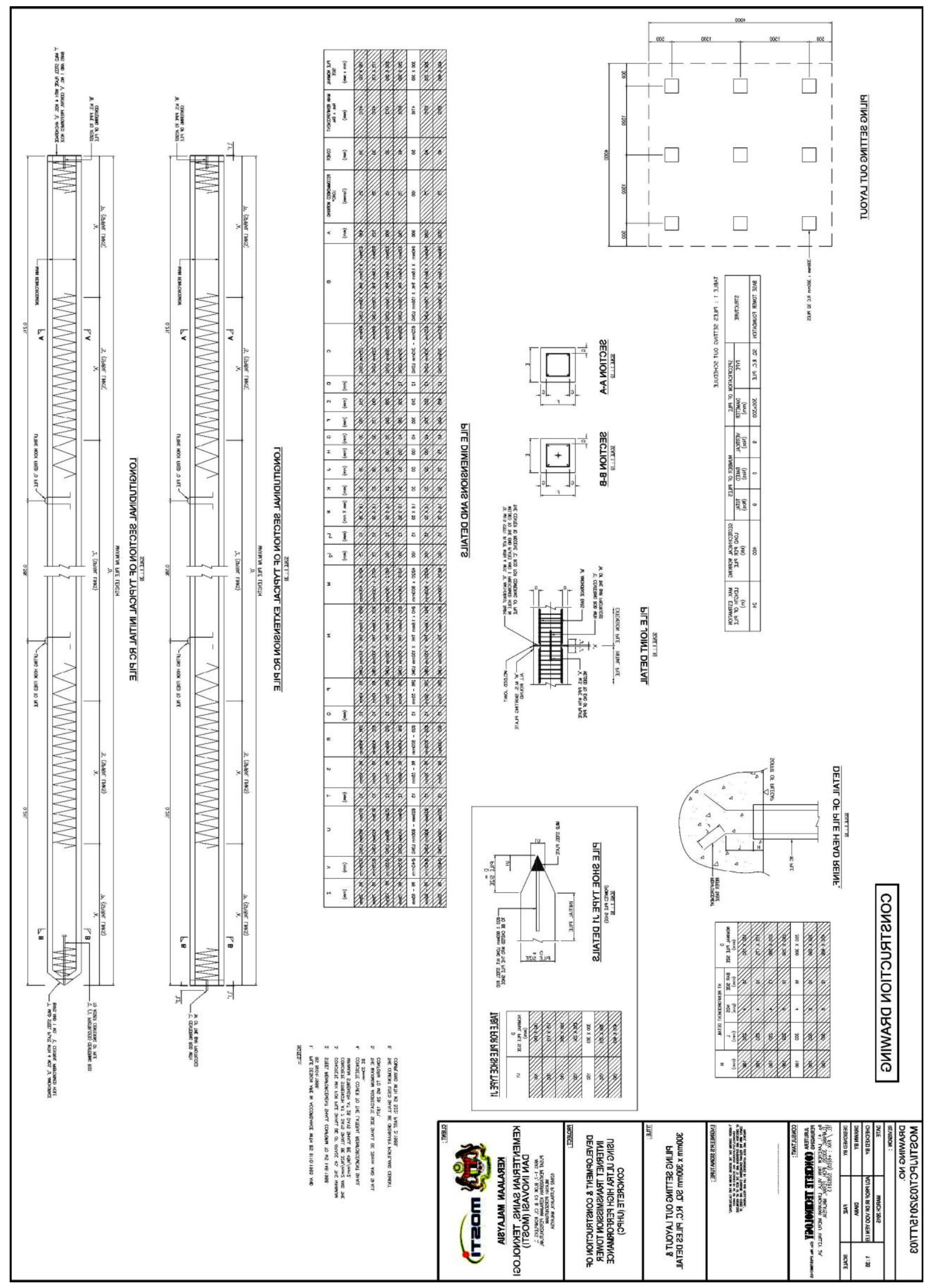




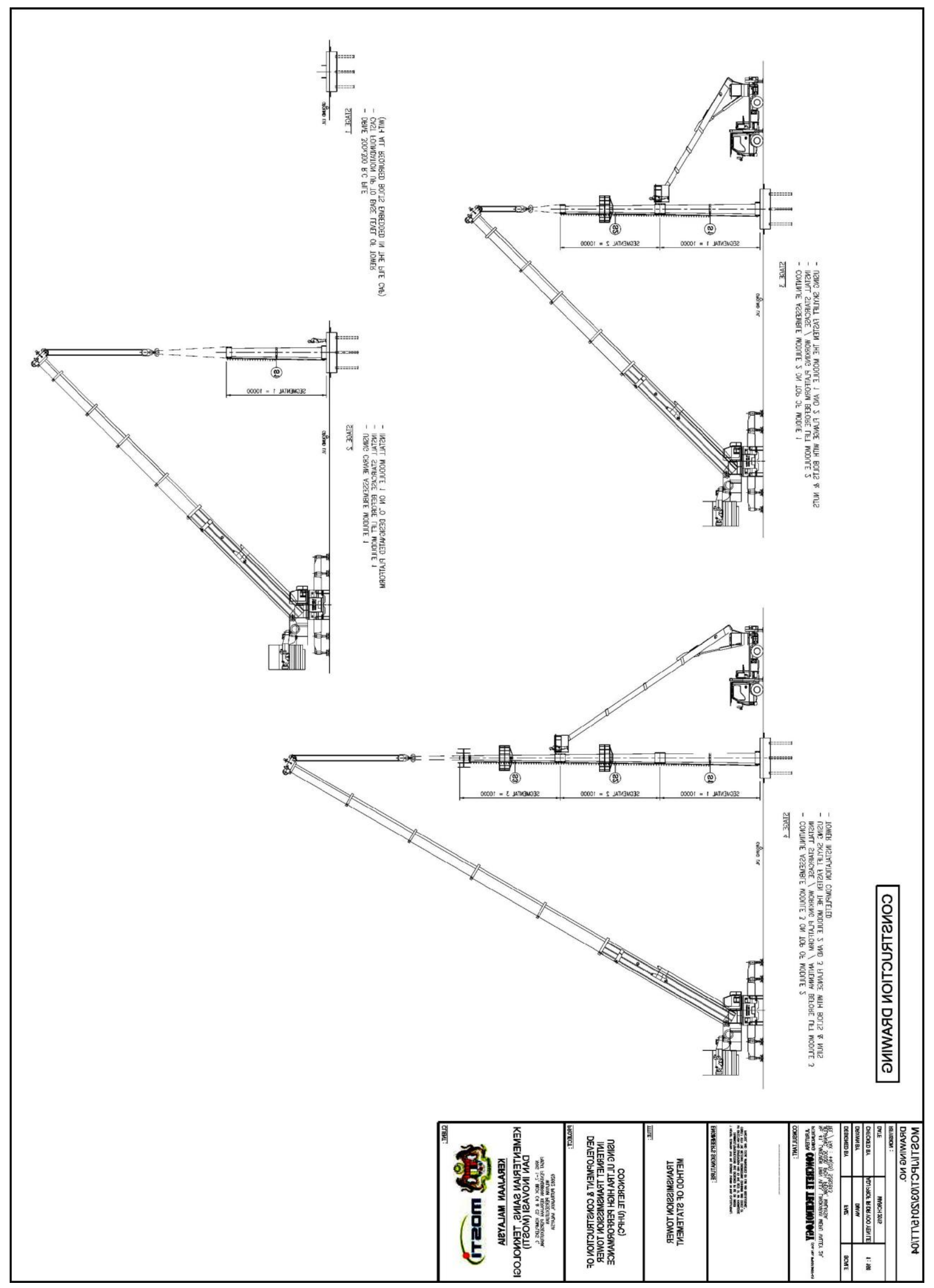

